\section{UENF SD 08 and UENF SD 09: Super-sweet corn hybrids for Northern Rio de Janeiro, Brazil}

\author{
Messias Gonzaga Pereira', Gabriel Moreno Bernardo \\ Gonçalves ${ }^{1 *}$, Nayara Norrene Lacerda Durães', Jocarla \\ Ambrosim Crevelari', José Arantes Ferreira Júnior ${ }^{1}$ and \\ Geovana Cremonini Entringer'
}

\begin{abstract}
The purpose of this study was to describe the main traits of the super-sweet maize cultivars 'UENF SD 08' and 'UENF SD 09', which produced higher yields than the control cultivar in the VCU (Value for Cultivation and Use) test series and proved to be competitive under the agro-climatic conditions of Northern and Northwestern Rio de Janeiro State.
\end{abstract}

Keywords: Zea mays L., plant breeding, yield, shrunken, green corn.

\section{INTRODUCTION}

Brazil is one of the world's leading maize grain producers. According to the Brazilian Institute of Geography and Statistics (IBGE), the country produced approximately 83 million tons of maize, i.e., a mean yield of around $5 \mathrm{t} \mathrm{ha}^{-1}$ in the 2017/2018 growing season (IBGE 2018a). According to the Agricultural Census 2017 in Brazil, almost 5 million tons of green corn were produced in that year and the Central-West region accounted for $94 \%$ of the output, followed by the Southeastern region, which accounted for 3\% (IBGE 2018b).

Rio de Janeiro State has the smallest number of agricultural production units in the Southeastern region. However, among 57 horticultural products listed by the IBGE, green corn ranks $15^{\text {th }}$ in number of producing units $(2018 \mathrm{~b})-$ behind traditional products such as lettuce, coriander, parsley, scallion, and others.

Fresh corn produced on small family farms is often a dual-purpose field corn, exploited for grain and fresh corn cobs, that does not meet the standards of texture quality and post-harvest longevity of sweet corn (Tracy 2001, Juvick et al. 2003).

Although farmers and even consumers know little about sweet maize in Brazil, the sweet corn market for the canning industry moved 1.44 billion BRL (Brazilian real) in 2016. Thus, sweet corn is a main product in the processed maize industry, second only to field corn used in the ultra-processed food industry (IBGE 2016).

Sweet corn can be used in different ways, e.g., as canned, frozen (ears or grains), dehydrated, fresh and baby corn, depending on the harvesting time, whereas the straw can be used as silage. In addition, distinct sweet corn-product types can meet different nutritional needs (Bandeira et al. 2012).
Crop Breeding and Applied Biotechnology 19: 235-239, 2019 Brazilian Society of Plant Breeding. Printed in Brazil http://dx.doi.org/10.1590/198470332019v19n2c33

\footnotetext{
*Corresponding author: E-mail: gabriel.agrobio@gmail.com (i) ORCID: 0000-0003-0103-7553
}

Received: 8 October 2018 Accepted: 13 December 2018

${ }^{1}$ Universidade Estadual do Norte Fluminense, Centro de Ciências e Tecnologias Agropecuárias, 28.013-602, Campos dos Goytacazes, RJ, Brazil 
Nevertheless, less than 70 sweet corn cultivars are registered in Brazil (MAPA 2018). This restricts the national maize productivity and competitiveness and invalidates the expansion of the production into regions where the crop is not traditionally cultivated.

Darcy Ribeiro Northern Rio de Janeiro State University (UENF) is running a super-sweet corn breeding program with the purpose of registering and releasing promising single-cross hybrids. The objective is to stimulate the regional economy and contribute to the development of sweet corn crops in Northern and Northwestern Rio de Janeiro State.

\section{BREEDING METHODS}

The UENF sweet corn breeding program was initiated with two heterotic field corn populations provided by the Federal University of Viçosa (UFV), designated CIMMYT (flint grain) and Piranão (dent grain), in the fifth reciprocal recurrent selection cycle.

After developing these populations, three additional reciprocal recurrent selection cycles with full-sib families were carried out in Northern and Northwestern Rio de Janeiro, i.e., a total of eight cycles. The improved populations (Piranão8 and CIMMYT8) were backcrossed with two supersweet corn genotypes, donated by EMBRAPA (shrunken donors), to generate four super-sweet corn populations: SH2-CIMMYT8 (CSH), SH2-8HS-CIMMYT8 (C8HS), SH2Piranão8 (PSH) and SH2-8HS-Piranão8 (P8HS) (Figure 1). These shrunken donors are the accessions designated SDSH2 and SD8HS of the UENF genebank (Santos et al. 2014).

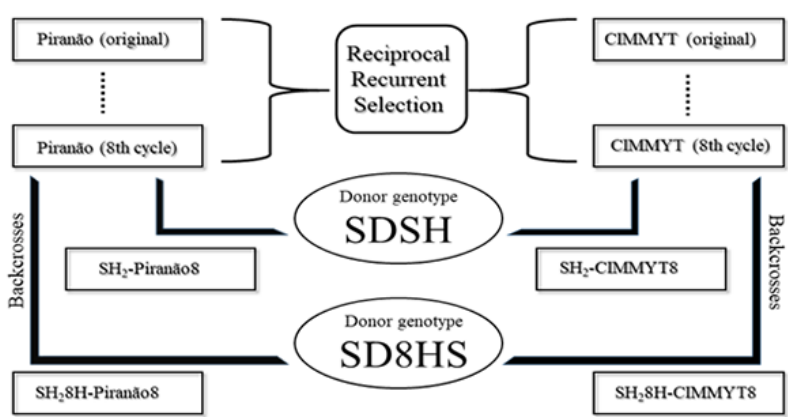

Figure 1. Breeding scheme for the development of the supersweet corn populations SH2-CIMMYT8, SH2-8HS-CIMMYT8, SH2-Piranão8 and SH2-8HS-Piranão8 from the field corn populations Piranão and CIMMYT, in eight cycles of reciprocal recurrent selection and backcrossing with the SDSH and SD8HS super-sweet corn genotypes donated by EMBRAPA. Redrawn with permission from Gonçalves et al. (2018).

Five inbred lines derived from each population (CSH, $\mathrm{C} 8 \mathrm{HS}, \mathrm{PSH}$ and P8HS) were selected after topcross trials. The lines were crossed between the heterotic groups Piranão x CIMMYT, based on a 10x10 partial diallel, resulting in 100 single-cross hybrids. These were evaluated in Itaocara and Campos dos Goytacazes in the 2015/2016 growing season, and the best inbred lines among them were selected for the following stage, based on the general and specific combining abilities (Durães et al. 2017).

Three inbred lines, each of the groups CSH, P8HS and PSH were selected and combined in $3 \times 6$ partial diallel to generate 18 single-cross hybrids (CSH group versus P8HS and PSH groups). These were evaluated in Value for Cultivation and Use (VCU) trials, in the North (Campos dos Goytacazes County) and Northwest (Itaocara County) of Rio de Janeiro, in two growing seasons (2016/2017 and 2017/2018), and the cultivars 'UENF SD 08' and 'UENF SD 09', derived from crosses between lines LCSH116 x LP8HS129 and LCSH116 x LP8HS130, respectively, were selected for yield, plant height, ear height, husk quality, ear diameter and ear length. Two cultivars were used as controls: the super-sweet corn cultivar 'Tropical Plus' developed by Syngenta (registered in 2005, with currently outstanding sweet corn production throughout the country); and field corn cultivar 'UENF 506-11', developed by UENF (adapted to Northern and Northwestern Rio de Janeiro). Cultivar 'Tropical Plus' is a single-cross hybrid, whereas cultivar 'UENF 506-11' is an interpopulational hybrid.

The following traits were evaluated to be used as selection criteria: ear yield without husk 23 days after silking (EY), plant height, ear height, husk quality (scores from 1 to $3: 1$ = complete husk cover; 2 = incomplete husk cover, without exposing the tip of the ear; and $3=$ exposed ear tip); ear diameter (ED) and ear length (EL).

\section{PERFORMANCE}

The VCU trials were arranged in a randomized complete block design with four replications and plots consisting of 3-m-long single rows. The rows were spaced $0.80 \mathrm{~m}$ and the plants $0.30 \mathrm{~m}$ apart, i.e., 41,666 plants per hectare.

The most important traits for producers, industry and consumers (EY, ED and EL) are listed in Table 1. In the combined analysis, the coefficient of variation (CV) of EY was $17.78 \%$, with a variation from 14.26 to $21.55 \%$ between environments; 
UENF SD 08 and UENF SD 09: Super-sweet corn hybrids for Northern Rio de Janeiro, Brazil

Table 1. Performance of the super-sweet corn cultivars UENF SD 08, UENF SD 09 and controls in the counties Itaocara and Campos dos Goytacazes, RJ, in the 2016/2017 and 2017/2018 growing seasons

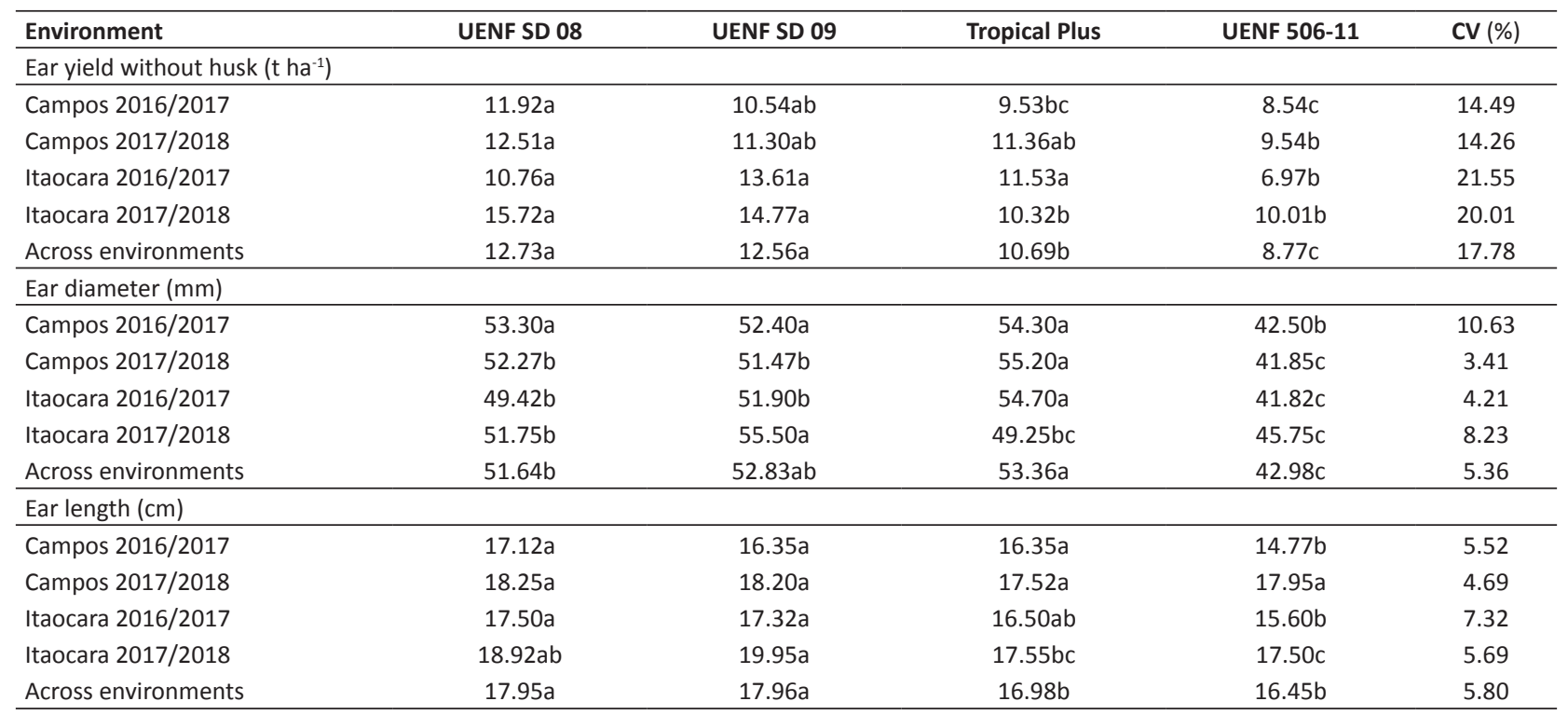

Different letters in a same row indicate significant differences (LSD, $\alpha=0.05$ )

the CV of ED was $5.36 \%$, varying from 3.41 to $4.21 \%$ between environments; and the CV of EL was 5.8\%, varying from 4.69 to $7.32 \%$ between environments.

According to the LSD test, based on a standard t table, the cultivars 'UENF SD 08' and 'UENF SD 09' had a better performance in all environments for the traits EY and EL than the controls 'Tropical Plus' and 'UENF 506-11'. However, the ED did not differ from that of the control 'Tropical Plus'.

\section{OTHER TRAITS}

Additional traits were evaluated based on the Cultivar Application Form of the National Register of Cultivars and the Brazilian Ministry of Agriculture, Livestock and Supply (RNC/MAPA).

The morphological traits, based on standardized maize descriptors for plant characterization, were analyzed at different stages. Since the cultivars 'UENF SD 08' and 'UENF SD 09' have the same genetic base, their morphological traits are similar, e.g.: rounded/spatulate first leaf, medium leaf angle, medium tassel branch angle, colorless tassel/ stigma, light-colored roots, yellow grains, straight grain rows and cylindrical ear shape. However, they had different leaf patterns: UENF SD 09 has curved leaves, whereas UENF SD 08 has strongly curved leaves.

With respect to other agronomic traits of interest, the cultivars 'UENF SD 08' and 'UENF SD 09' had super-early to early cycles, according to the sowing date. Temperatures tend to increase rapidly before the end of the winter in Northern and Northwestern Rio de Janeiro, reaching a mean of more than $24^{\circ} \mathrm{C}$. This temperature condition shortens the cycle of cultivars sown after spring and favors super-early maturation (Table 2).

The plant height of both cultivars was medium to large; however, in this case, lodging is not an issue, since maize plants for green corn are less exposed to the risks of lodging than plants left to ripen until full maturation. The plants were not very prolific, but produced large ears, with 14 grain rows per ear and a good husk cover (Table 2).

Based on the evaluation methodology described by Agroceres (1996), applied 30 days after silking, i.e., after the period indicated for harvesting ( 23 days), the resistance of the maize plants to the main diseases was considered good (Table 2). 
Table 2. Agronomic trait means of the cultivars UENF SD 08 and UENF SD 09 in tests of Value for Cultivation and Use (VCU)

\begin{tabular}{lcc}
\hline Agronomic traits & UENF SD 08 & UENF SD 09 \\
\hline Growing degree-days ${ }^{1}$ & 900 ( 60-65 days) & 915 ( 60-65 days) \\
Plant height $(\mathrm{m})$ & 2.38 & 2.52 \\
Ear height $(\mathrm{m})$ & 1.49 & 1.62 \\
Number of ears per plant & 1.1 & 1.1 \\
Number of grain rows & 14 & 14 \\
Husk cover & $1.6($ Good) & $1.6(\mathrm{Good})$ \\
& Disease resistance ${ }^{2}$ & Resistant \\
Exserohilum turcicum & Moderately Resistant & Resistant \\
Puccinia sorghi & Resistant & Resistant \\
\hline
\end{tabular}

${ }^{1}$ Growing degree-days to silking; ${ }^{2}$ Evaluation 30 days after after silking.

\section{SEED PRODUCTION}

The cultivars 'UENF SD 08' and 'UENF SD 09' were registered by the Ministry of Agriculture, Livestock and Supply, on May 24 (N. 38733) and 25, 2018 (N. 38734), respectively. The State University of Northern Rio de Janeiro (UENF) is responsible for the basic seed production.

\section{CONCLUSION}

The super-sweet corn cultivars 'UENF SD 08' and 'UENF SD 09' are high-yielding and have large-sized ears, aside from being resistant to the main maize diseases. They are well adapted to the Northern and Northwestern regions of Rio de Janeiro State, which includes 21 counties (Campos dos Goytacazes, São Fidelis, Cambuci, Cardoso Moreira, Itaocara, Miracema, Itaperuna, among others).

\section{ACKNOWLEDGEMENTS}

The authors are indebted to the FAPERJ (Fundação Carlos Chagas Filho de Amparo a Pesquisa do Estado do Rio de Janeiro) for providing a scholarship and funding the field studies.

\section{REFERENCES}

AGROCERES (1996) Guia Agroceres de sanidade. Sementes Agroceres, São Paulo, 72p.

Bandeira CM, Evangelista WP and Gloria MBA (2012) Bioactive amines in fresh, canned and dried sweet corn, embryo and endosperm and germinated corn. Food Chemistry 131: 1355-1359.

Durães NNL, Crevelari JA, Vettorazzi JCF, Junior JAF, Santana FA and Pereira MG (2017) Combining ability for traits associated with yield and quality in super sweet corn (Zea mays L. saccharata). Australian Journal of Crop Science 11: 1188-1194.

Gonçalves GMB, Pereira MG, Ferreira Júnior JA, Schwantes IA, Durães NNL, Crevelari A and Amara Junior AT (2018) Development and selection of super-sweet corn genotypes (sh2) through multivariate approaches. Bragantia 77: 536-545.

IBGE - Instituto Brasileiro de Geografia e Estatística (2016) Pesquisa industrial anual. Available at: $<$ https://www.ibge.gov.br/estatisticasnovoportal/economicas/industria/9044-pesquisa-industrial-anualproduto.html?=\&t=resultados $>$. Accessed on Sept 4, 2018.
IBGE - Instituto Brasileiro de Geografia e Estatística (2018a) Levantamento sistemático da produção agrícola: produção de cereais, leguminosas e oleaginosas - comparação entre as safras 2017 e 2018 - Brasil e grandes regiões. Available at: <https://www.ibge.gov.br/estatisticasnovoportal/economicas/agricultura-e-pecuaria/9201-levantamentosistematico-da-producao-agricola.html? $=\& \mathrm{t}=$ resultados $>$. Accessed on Sept 4, 2018.

IBGE - Instituto Brasileiro de Geografia e Estatística (2018b) Censo agropecuário 2017: número de estabelecimentos agropecuários e quantidade produzida, por produtos da horticultura. Available at: <https://www.ibge.gov.br/estatisticas-novoportal/economicas/ agricultura-e-pecuaria/21814-2017-censo-agropecuario. html?=\&t=resultados $>$. Accessed on Sept 4, 2018.

Juvick JA, Yousef GG, Tadmor Y, Han T, Azanza F, Tracy WF, Bar-Zur A and Rocheford TR (2003) QTL influencing kernel chemical composition and seedling stand establishment in sweet corn with the shrunken 2 and sugary enhancer1 endosperm mutations. Journal of the American Society for Horticultural Sciencis1 28: 864-875.

MAPA - Ministério da Agricultura, Pecuária e Abastecimento (2018) 
UENF SD 08 and UENF SD 09: Super-sweet corn hybrids for Northern Rio de Janeiro, Brazil

CULTIVARWEB: Gerenciamento de informação. Available at: <http:// sistemas.agricultura.gov.br/snpc/cultivarweb/cultivares_registradas. php>. Accessed on Sep 4, 2018.

Santos PHAD, Pereira MG, Trindade RDS, Cunha KSD, Entringer GC and Vettorazzi JCF (2014) Agronomic performance of super-sweet corn genotypes in the north of Rio de Janeiro. Crop Breeding and Applied Biotechnology 14: 8-14.

Tracy WF (2001) Sweet corn. In Hallauer AR (ed) Specialty corn. CRC Press, Boca Raton, p.155-198. 